\title{
Reaction Mechanism of Arsenic Capture by a Calcium-based Sorbent during the Combustion of Arsenic-Contaminated Biomass: A pilot-scale experience
}

Authors: Mei Lei ${ }^{1,2 *}$, Ziping Dong ${ }^{1,2}$, Ying Jiang ${ }^{3}$, Philip Longhurst ${ }^{3}$, Xiaoming Wan ${ }^{1,2}$, Guangdong Zhou ${ }^{1}$

1. Center for Environmental Remediation, Institute of Geographic Sciences and Natural Resources Research, Chinese Academy of Sciences, Beijing, 100101, China

2. University of Chinese Academy of Sciences, Beijing, 100049, China

3. School of Water, Energy, and Environment, Cranfield University, Cranfield, MK43 0AL, UK

\begin{abstract}
Large quantities of contaminated biomass due to phytoremediation were disposed through combustion in low-income rural regions of China. This process provided a solution to reduce waste volume and disposal cost. Pilot-scale combustion trials were conducted for in site disposal at phytoremediation sites. The reaction mechanism of arsenic capture during pilot-scale combustion should be determined to control the arsenic emission in flue gas. This study investigated three Pteris vittata L. biomass with a disposal capacity of $600 \mathrm{~kg} / \mathrm{d}$ and different arsenic concentrations from three sites in China. The arsenic concentration in flue gas was greater than that of the national standard in the trial with no emission control, and the arsenic concentration in biomass was $486 \mathrm{mg} / \mathrm{kg}$. CaO addition notably reduced arsenic
\end{abstract}


emission in flue gas, and absorption was efficient when $\mathrm{CaO}$ was mixed with biomass at $10 \%$ of the total weight. For the trial with $10 \% \mathrm{CaO}$ addition, arsenic recovery from ash reached $76 \%$, which is an eight fold increase compared with the control. Synchrotron radiation analysis confirmed that calcium arsenate is the dominant reaction product.

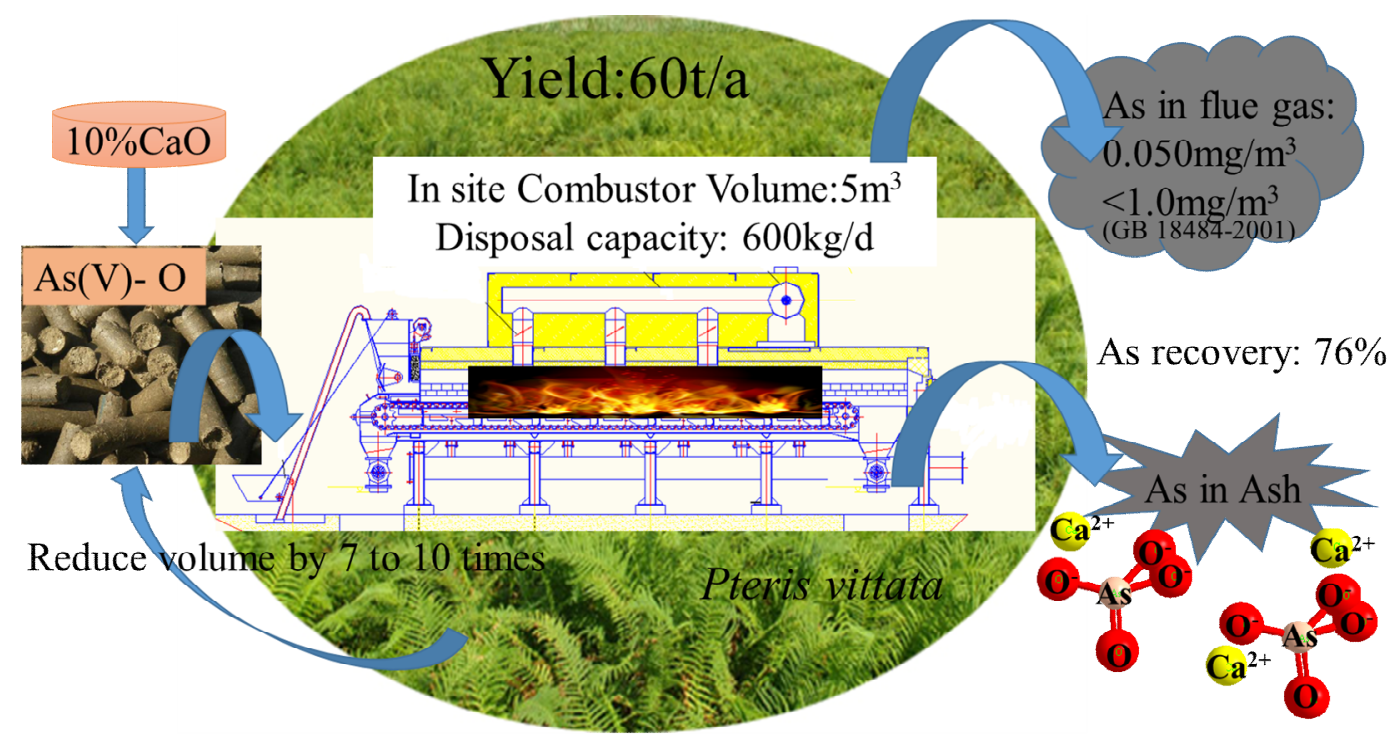

Keywords: Arsenic contamination; Phytoremediation; Emission control; Calcium-based sorbent; Biomass disposal; pilot-scale combustion. 


\section{Introduction}

Pteris vittata L. was found to be a promising plant to remediate arsenic (As)-contaminated soils, as demonstrated in various lab and pilot-scale studies (Chen et al., 2006; Kertulis-Tartar et al., 2006). A 19.5ha field pilot-scale application of planting $P$. vittata L. was conducted in China for 2 years (Wan et al., 2016).

However, a main constraining factor for the wide and profitable application of phytoremediation is the disposal of large quantities of As-hyperaccumulator plant biomass (Dhir et al., 2012; Sas-Nowosielska et al., 2004). Many previous studies have suggested thermochemical biomass conversions, such as combustion, gasification, and pyrolysis, to achieve biomass volume reduction and renewable energy production (Jiang et al., 2015). Many previous studies have shown that $\mathrm{As}, \mathrm{Pb}, \mathrm{Cd}$, and $\mathrm{Zn}$ are found in gaseous emissions at low temperatures during thermochemical processes (Nzihou and Stanmore, 2013; Pudasainee et al., 2014). In particular, studies have shown that As is mostly present in the gas phase as arsenic oxide $\left(\mathrm{As}_{2} \mathrm{O}_{3}\right)$ at low temperature during the thermochemical treatment of As-contaminated biomass $\left(<500^{\circ} \mathrm{C}\right)$ (Nzihou and Stanmore, 2013; Contreras et al., 2009). Considerable previous studies on controlling elemental contaminant emissions during coal combustion have suggested the injection of mineral sorbents to capture As and other metal elements in situ in a combustion system (Gullett and Raghunathan, 1994; Jadhav and Fan, 2001; Mahuli et al., 1997). Gullett and Raghunathan (Gullett and Raghunathan, 1994) used four mineral sorbents in a pilot-scale combustion study to determine the As capture efficiency. They showed that $\mathrm{Ca}(\mathrm{OH})_{2}$ and $\mathrm{CaO}$ remarkably improve the recovery of As and other trace 
elements in the processed ash. Subsequently, Mahuli et al. (Mahuli et al., 1997) investigated the As capture efficiency of four mineral sorbents, namely, $\mathrm{Ca}(\mathrm{OH})_{2}$, kaolinite, alumina, and silica. X-ray diffraction and synchrotron radiation analysis showed that calcium arsenate $\left(\mathrm{Ca}_{3}\left(\mathrm{AsO}_{4}\right)_{2}\right)$ is the dominant reaction product in the ash and indicated that chemical absorption is the main As capture mechanism. Jadhav and Fan (Jadhav and Fan., 2001) conducted a laboratory-scale study about the reaction mechanism of As capture by using a calcium-based sorbent. $\mathrm{As}_{2} \mathrm{O}_{3}$ vapors were used as the source of arsenic with a concentration ranging from $7 \mathrm{ppm}$ to $32 \mathrm{ppm}$ in each experiment. The reaction of $\mathrm{As}_{2} \mathrm{O}_{3}$ with $\mathrm{CaO}$ was evaluated over a wide temperature range of $300{ }^{\circ} \mathrm{C}-1000{ }^{\circ} \mathrm{C}$. The thermal stability of the generated arsenates increased in the order $\mathrm{CaAs}_{2} \mathrm{O}_{6}\left(750{ }^{\circ} \mathrm{C}\right)<\mathrm{Ca}_{2} \mathrm{As}_{2} \mathrm{O}_{7}\left(950{ }^{\circ} \mathrm{C}\right)<\mathrm{Ca}_{3} \mathrm{As}_{2} \mathrm{O}_{8}$ $\left(1400{ }^{\circ} \mathrm{C}\right)$. Most of the previous experimental studies have dealt with either coal or chromated copper arsenate (CCA)-treated wood. As normally exists in coal either in organic/pyrite bound and micro-mineral forms (Liu et al., 2009) or as $\mathrm{CrAsO} 4$ precipitate in CCA-treated wood (Helsen and Van Den Bulck, 2000). However, As is a biologically accumulated element and mostly exists as arsenite in plant biomass, such as As accumulating fronds of $P$. vittata (Huang et al., 2004). In addition, the combustion conditions are relatively different for the considerable variations of proximate analysis and element concentrations of biomass and coal. Thus, an experimental study is needed to better understand the volatilization of As and the effectiveness of calcium sorbents during the combustion of As-accumulating plant biomass. This study reported the feasibility and efficiency of adding calcium-based sorbents during the phytoremediation of biomass combustion in a pilot-scale combustion furnace with a disposal 
capacity of $600 \mathrm{~kg} / \mathrm{d}$. A pilot-scale experiment is difficult to control compared with laboratory-scale work. To the best of our knowledge, this is the first reported large-scale study that investigates the injection of sorbents during the phytoremediation of biomass combustion. This study provides valuable insight into As emission control during the thermochemical treatment of As-contaminated biomass. The result serves as a guide to enhance the feasibility and environmental benefits of phytoremediation projects.

\section{Materials and Methods}

\subsection{Biomass fuel materials}

The aerial parts of $P$. vittata biomass used in this study were collected from three pilot-scale As phytoremediation sites, namely, Jiyuan (JY), Hunan (HN), and Guangxi (GX). The arsenic concentration of biomass remarkably varies among the three sites. The JY site is located in Henan Province in Central China. Phytoremediation work started in 2012, and the site was contaminated with high concentrations of As and other metal contaminants released by local metal smelting industries. An area of $4,667 \mathrm{~m}^{2} P$. vittata planting was established on the site with a plant density of $50 \mathrm{~cm} \times 50 \mathrm{~cm}$.

The HN site is located in Hunan Province in South Central China. The remediation project started in 2014 on a legacy site owned by a local As smelting factory. The $P$. vittata planting area on the site is $73,337 \mathrm{~m}^{2}$, and the entire site was divided into three different plots. Plant densities were expressed as follows: $4667 \mathrm{~m}^{2}$ at a plant density of $40 \mathrm{~cm} \times 40 \mathrm{~cm}, 54003 \mathrm{~m}^{2}$ at $30 \mathrm{~cm} \times 40 \mathrm{~cm}$, and $12000 \mathrm{~m}^{2}$ at $30 \mathrm{~cm} \times 30 \mathrm{~cm}$. 
The GX site is located in South Central China. Similar to the two other sites, As contamination was caused by a local smelting factory, which was closed in 2005. Phytoremediation work started in 2014 on the site with an area of $4267 \mathrm{~m}^{2}$ of P. vittata and planting density of $40 \mathrm{~cm} \times 40 \mathrm{~cm}$.

\subsection{Biomass Feedstock Preparation and Characterization}

All $P$. vittata biomass samples used in this study were air-dried until a water content of $\sim 8 \%$ was achieved. The dried samples were shredded into $\sim 5 \mathrm{~mm}$ size and pelletized into small granules with $1 \mathrm{~cm}$ diameter and $4.5 \mathrm{~cm}$ length and a density of $1.34 \mathrm{~g} / \mathrm{cm}^{3}$. The pelletized material is suitable as fuels due to its low calorific value (CV). Pelletized feedstocks have high particle and bulk densities compared with other biomass (Simone et al., 2012).

Pelletization increases the combustion stability and reduces the volume of raw material by 7 to 10 times and achieves a remarkable reduction in storage space. For As chemical capture tests, $\mathrm{CaO}$ was blended with JY biomass as a chemical sorbent at $5 \%, 10 \%$, and $15 \%$ of feedstock weight. $\mathrm{CaO}$ and biomass was blended by using a rotary mixer until the $\mathrm{CaO}$ and biomass are thoroughly mixed. The mixtures were pelletized into the same size of granules as other biomass samples. The mixing and compacting processes ensure the maximum contact between $\mathrm{CaO}$ additive and biomass, which promote the reactions (Neeft et al., 1997).

The dried biomass samples were digested by using $1 \mathrm{ml}$ of concentrated $\mathrm{HClO}_{4}$ solution and 5 $\mathrm{ml}$ of concentrated $\mathrm{HNO}_{3}$ following the method from Yan (Yan et al., 2008) and Chen (Chen et al., 2002). The As concentration in the solutions was analyzed by using an atomic fluorescence spectrometer (AFS-9800, Haiguang Instrumental Co., China). Other elements (P, 
$\mathrm{K}, \mathrm{Na}, \mathrm{Ca}, \mathrm{Mg}, \mathrm{Pb}, \mathrm{Cu}, \mathrm{Zn}$, and Fe) were determined by using an ICP-MS (Optima $5300 \mathrm{DV}$, PE, USA). Standard reference materials for plants (GBW-07603 and GBW-08501) obtained from the China National Center for Standard Reference Materials were processed and analyzed by using the same method. Proximate analysis was conducted by using standard analytical methods (ASTM E871 and E872) to determine the moisture, ash, and volatile matter content. $\mathrm{C}, \mathrm{H}, \mathrm{N}, \mathrm{O}$, and $\mathrm{S}$ compositions of the sample were analyzed by using an elemental analyzer (Elementar Analysensysteme GmbH, Germany). The elemental analyzer operating at CHNS mode with oxygen content was calculated based on difference. CVs for the samples were determined in accordance with ASTM D2015. Samples were dried to constant weight and finely ground before analyzing the high heating values using a bomb calorimeter (SDC5015, Hunan Sundy Co. Ltd., China).

Thermal behavior of $P$. vittata samples were investigated by using a simultaneous thermogravimetric (TG) analyzer (SDT-Q600, TA Instruments, US). Biomass samples were ground into fine powder by using a mesh grinder fitted with an 80 mesh $(0.074 \mathrm{~mm})$. Biomass sample (20 mg) was placed in the crucible, where the temperature was measured by using a thermocouple attached to the container. The temperature increased from ambient temperature $\left(30{ }^{\circ} \mathrm{C}\right)$ to $800^{\circ} \mathrm{C}$ at a heating rate of $25^{\circ} \mathrm{C} \mathrm{min}^{-1}$. Air was used as the carrier gas for the tests with the gas flow rate maintained at $20 \mathrm{ml} \mathrm{min}^{-1}$.

\subsection{Combustor Assembly, Biomass Combustion, and As Chemical Capture Experiment}

Biomass combustion experiments were conducted in a chain-grate boiler type incinerator with a combustion furnace internal volume of $5 \mathrm{~m}^{3}$. The burner is connected to an emission 
collection system with a cooling tower, that is, a bag-type dust collector and a water spraying tower. During operation, the combustion temperature was monitored and maintained at $850 \pm 10^{\circ} \mathrm{C}$ by using a thermocouple. For each combustion trial, biomass feedstock was fed in the boiler at a constant rate of $1.25 \mathrm{~kg} \mathrm{~min}^{-1}$ for $1 \mathrm{~h}$, and the feedstock was burned. The gas residence time in the boiler was $1.25 \mathrm{~s}$. Bottom ashes were collected in ash collection unit 1 with hot flue gas cooled first before entering the dust collector and spray tower. Fly ash was captured at the cooling tower, and dust and ash were collected in ash collection units 2 and 3 , respectively. Following the gas cleaning process, flue gas was discharged in the spray tower before discharge in the atmosphere via a chimney, and the spray tower was used to settle the particles in the flue gas. The flow rate was modulated by controlling the by-pass valve of the blower. A schematic of the incineration equipment is shown in Fig. 1.

Three biomass combustion test controls were conducted on pelletized HN, GX, and JY biomass samples. In addition, another three biomass combustion tests were performed on JY biomass samples with $\mathrm{CaO}$ addition at $5 \%, 10 \%$, and $15 \%$. The operational parameters for all combustion trials are shown in Table 1. 


\subsection{Ash and flue gas sampling and analysis}

After each combustion test, bottom and fly ashes collected in ash collection units were weighed. Representative ash samples were digested by using US Environmental Protection Agency Method 3050B. The digested solutions were analyzed for As concentration by using an atomic fluorescence spectrometer (AFS-9800, Haiguang Instrumental Co., China).

X-ray absorption fine structure (XAFS) was performed to investigate the bottom and fly ash samples to provide key structural information of calcium-arsenic compounds. The ash samples were prepared and analyzed based on a standard method (ASTM D934). Briefly, ash samples and a reference As compound $\mathrm{Ca}_{3}\left(\mathrm{AsO}_{4}\right)_{2}$ were packed in a $3 \mathrm{~cm} \times 0.7 \mathrm{~cm}$ sample holder. As K-edge $(11867 \mathrm{eV}) \mathrm{X}$-ray absorption spectra were operated at the extended X-ray adsorption fine structure (EXAFS) station on Beamline 1W1B of Beijing Synchrotron Radiation Facility. The X-ray absorption near edge structure(XANES) spectra were collected at room temperature in fluorescence mode. The energy range of the incident X-ray beam was $11800-12800 \mathrm{eV}$. A gold foil was placed between the second and third ionization chambers for energy calibration. The entire XAF spectra were background corrected and normalized. Data reduction was accomplished in IFFEFIT software package.

The flue gas of each combustion trial was sampled by using a heated isokinetic probe placed at the gas sampling port of the chimney. The temperature of isokinetic probe was maintained at $120 \pm 20^{\circ} \mathrm{C}$. The gaseous elemental emissions were absorbed and retained by $5 \%(\mathrm{v} / \mathrm{v})$ nitric acid $\left(\mathrm{HNO}_{3}\right) / 10 \%$ hydrogen peroxide $\left(\mathrm{H}_{2} \mathrm{O}_{2}\right)$ in two 
ice-bath-chilled impingers. This method is in accordance with the China State Environmental Protection Administration standard method for monitoring and analysis of air and flue gas. The collected flue gas samples were analyzed for total As content by using an atomic fluorescence spectrometer (AFS-9800, Haiguang Instrumental Co., China).

\subsection{Chemical Sorbent Performance Indicator}

The percentage of As recovered in ash content $\left(E_{\text {ash }}\right)$ during a combustion trial is calculated by using Equation 1:

$E_{\text {ash }}=\frac{C_{1} \times M_{1}+C_{2} \times M_{2}+C_{3} \times M_{3}+C_{4} \times V}{C_{0} \times M_{0} \times(1-w)} \times 100 \%, \quad$ (Equation 1)

where:

$C_{1}, C_{2}$, and $C_{3}$ are the As concentrations (in $\mathrm{mg} \mathrm{kg}^{-1}$ ) in bottom, condensation fly, and dedusting fly ashes, respectively. $M_{1}, M_{2}$, and $M_{3}$ are the weights of (in $\mathrm{kg}$ ) bottom, condensation fly, and dedusting fly ashes, respectively. $\mathrm{C}_{4}$ is the As concentration in spray liquid ( $\mathrm{mg} \mathrm{l}^{-1}$ ), $\mathrm{V}$ is the volume of the spray liquid (1), $C_{0}$ is the As concentration in biomass feedstock (in $\mathrm{mg} \mathrm{kg}^{-1}$ ), $M_{0}$ is the input feedstock weight $(\mathrm{kg}$ ), and $\varpi$ is the moisture content of the feedstock (in \%).

The As content in flue gas can be calculated by using Equation 2:

$A s_{\text {gas }}=c \cdot Q \cdot t$

(Equation 2)

where $c$ is the As concentration (in $\mathrm{L} / \mathrm{min}$ ) in flue gas, $Q$ is the gas flow rate (in $\mathrm{L} / \mathrm{min}$ ), and $t$ is the combustion time (in $\min$ ).

To understand the mass balance of As during combustion, total As recovery $\left(E_{\text {Total }}\right)$ is calculated by using Equation 3. 


$$
E_{\text {total }}=\frac{C_{1} \times M_{1}+C_{2} \times M_{2}+C_{3} \times M_{3}+C_{4} \times V+A s_{g a s}}{C_{0} \times M_{0} \times(1-\varpi)} \times 100 \%
$$

\section{Results and Discussion}

\subsection{Sample analysis and characterisation}

The proximate and ultimate analysis results and trace element concentrations of $P$. vittata biomass samples are summarized in Tables 2 and 3.

The weight of biomass samples remarkably reduced based on the result of TG analysis (TGA) in Figure 2. The ash contents of $P$. vittata biomass from three different origins were found to be $\mathrm{JY}>\mathrm{GX}>\mathrm{HN}$. This finding is in agreement with the TG results.

TGA on P. vittata biomass samples indicated a typical four-stage thermal devolatilization process, namely, stage1: drying, stage2: devolatilization (char forming), stage3: char combustion, and stage4: ash decomposition, as shown in Figure 2. The key thermal devolatilization characteristics of HN, GX, and JY biomass samples are summarized in Table 4.

\subsection{Fate of As during Combustion Trials}

As contaminants undergoes a solid-to-gaseous phase transformation during the combustion of $P$. vittata at low combustion temperature. An improved understanding of the As distribution in the processed ash, flue gas, and spraying liquor is key for As emission control and potential As recovery. During each combustion trial, the quantities of As in the processed ash, spray liquor, and flue gas were calculated. The results are summarized in Table 5. The flue gas testing list includes soot, blackness, $\mathrm{CO}, \mathrm{NOx}, \mathrm{SO}_{2}, \mathrm{HCl}$, and $\mathrm{HF}$. All concentration levels of other pollutants were below 
the national standards for pollution control. The concentrations of other pollutants in flue gas are shown in Table 6. For the control combustion trials without $\mathrm{CaO}$ addition, the As found in the ash residual only accounted for $\sim 10 \%$ of the total As in the biomass feedstock. Meanwhile, for the combustion trials with $\mathrm{CaO}$ addition, the percentages of retained As in the processed ash remarkably increased to $48 \%, 76 \%$, and $69 \%$ for the three $\mathrm{CaO}$ addition ratios of $5 \%, 10 \%$, and $15 \%$. This condition resulted in a reduction of As concentration in the flue gas from $6.1 \times 10^{-2} \mathrm{mg}^{-1}$ in the control trial to $1.1 \times 10^{-2}, 0.5 \times 10^{-2}$, and $0.8 \times 10^{-2} \mathrm{mg}^{-1}$. The $\mathrm{CaO}$ mixing ratio at $10 \%$ appears to be the most efficient to achieve high As retention in ash forms ( $\sim$ five fold increase in bottom ashes and $\sim 34$-fold increase in fly ashes compared with the control). This condition remarkably reduced the As emissions in the flue gas, as shown in Table 5.

In previous studies, researchers conducted several combustion experiments of $P$. vittata with $0.2000 \mathrm{~g}$ in each trial, and other researchers focused on the combustion of zinc and cadmium hyperaccumulator and CCA combustion with disposal capacities of 1.5 L and 10 L, respectively (Yan et al., 2008; Zhong et al., 2015; Helsen and Van Den Bulck, 2000). The disposal scale in this research is the largest in site. The combustion trials with $\mathrm{CaO}$ addition showed an improved As capture when the $\mathrm{CaO}$ was increased from $5 \%$ to $10 \%$. This condition is due to the additional chemical sorbent that is available to react with As. However, the As capture reduced markedly compared with $10 \% \mathrm{CaO}$ addition when $\mathrm{CaO}$ was added at $15 \%$ of the total feedstock weight. This condition is due to the agglomeration and scorification of feedstock particles during 
combustion, which reduce the contact areas of biomass feedstock with $\mathrm{CaO}$.

Consequently, this condition reduces the catalytic efficiency of $\mathrm{CaO}$ in the thermal process and reaction rate between $\mathrm{CaO}$ and As oxides (Struis et al., 2002), which leads to a reduced kinetic reaction of As sorption.

The ash recovery is the ratio of the ash product content to the ash content in biomass, which increases from $52.5 \%, 45.8 \%$, and $44.6 \%$ to $86.5 \%, 80.1 \%$, and $81.1 \%$, respectively, with $\mathrm{CaO}$ addition. This finding indicates the approximately half of the ashes are left in the combustor in the trials without $\mathrm{CaO}$ and approximately $80 \%$ of the ashes are left in the combustor in the trials with $\mathrm{CaO}$. The As recovery is poor to a certain extent in the trials because the length of vertical stack is short to stabilize the flow to conduct credible sampling of particulates. In the inclined section leading to the vertical discharge pipe, the particles tend to settle and are lost to sampling. $E_{a s h-a}$ is the As recovery by adding those As contents in the lost ash. The recovery reaches 94.85 with the addition of $10 \% \mathrm{CaO}$. $E_{a s h-a}$ of the GX and JY trials is lower than that of the $\mathrm{HN}$ trial. This condition may be related to the ratio of As content to the total content of $\mathrm{Ca}$ and $\mathrm{Mg}$ in the biomass.

\subsection{Reaction Mechanism of As Capture by Ash}

As a medium volatile element, As is absorbed in fly ash through different means with the decrease of temperature. As is easily enriched in fly ash with microparticles (Zhang et al., 1999). As emission should be controlled during the emission of microparticles. Meanwhile, volatile gases, such as $\mathrm{As}_{2} \mathrm{O}_{3}$, can be dissolved in silicate melt (Guo et al., 2004), and only a fraction of As is absorbed in silicate melt during 
combustion.

As clearly demonstrated in the $\mathrm{CaO}$ addition experiment, $\mathrm{CaO}$ has a remarkable effect on retaining the As in solid residuals. This condition consequently reduces the gaseous As in the flue gas. Previous studies have shown that As capture by $\mathrm{CaO}$ involves a simple physical adsorption and results in an irreversible chemical reaction that leads to solid forms of $\mathrm{Ca}-\mathrm{As}-\mathrm{O}$ products, such as $\mathrm{Ca}_{3}\left(\mathrm{AsO}_{4}\right)_{2}$ and $\mathrm{Ca}_{2} \mathrm{As}_{2} \mathrm{O}_{7}$ (Jadhav and Fan, 2001; Li et al., 2007; Hirsch et al., 2000; Sterling and Helble, 2003). In a previous study, $\mathrm{AsO}_{2}(\mathrm{~g})$ and $\mathrm{AsO}(\mathrm{g})$ were supposed to be the most possible species at temperatures higher than $800{ }^{\circ} \mathrm{C}$ with the co-combustion of coal and oil waste. $\mathrm{As}_{2} \mathrm{O}_{5}$ was the main specie when the temperature was less than $300{ }^{\circ} \mathrm{C}$. In this condition, the interaction of As with fly ash components $(\mathrm{Na}, \mathrm{K}, \mathrm{Ca}, \mathrm{Mg}, \mathrm{Fe}, \mathrm{Al}$, and $\mathrm{Si}$ ) was not considered. $\mathrm{Ca}\left(\mathrm{AsO}_{2}\right)_{2}$ and $\mathrm{Ca}_{3}\left(\mathrm{AsO}_{4}\right)_{2}$ exited at $650-750{ }^{\circ} \mathrm{C}$ and over $700{ }^{\circ} \mathrm{C}$, respectively, when the interaction was considered (Contreras et al., 2009). Thus, few studies have reported the exact speciation of $\mathrm{Ca}-\mathrm{As}-\mathrm{O}$ compounds due to As capture using $\mathrm{CaO}$, especially in the context of biomass combustion. In this study, detailed information on the chemical structure was obtained from fly ash and bottom ash samples through state-of-the-art XRAS instrumentation. This study provides considerable insights into the reaction mechanism of $\mathrm{As}-\mathrm{CaO}$ interaction under combustion conditions.

Results of XANES analysis (Fig. 3) showed the presence of $\mathrm{Ca}_{3}\left(\mathrm{AsO}_{4}\right)_{2}$, calcium carbonate, and unreacted $\mathrm{CaO}$. No As oxides were found, which indicates that physical adsorption is not the dominant As fixation mechanism in the fly ash. The results of ash 
samples indicate the oxidation of $\mathrm{As}(\mathrm{III})$ to $\mathrm{As}(\mathrm{V})$.

According to many studies (Hirsch et al., 2000; Chesworth et al., 1994; Frandsen et al., 1994; Ratafia-Brown, 1994; Bool and Helble, 1995), As mainly exists in the gaseous form of $\mathrm{As}_{2} \mathrm{O}_{3}$ in the combustion environment, when the temperature is greater than $500{ }^{\circ} \mathrm{C}$. At the temperature range of $227^{\circ} \mathrm{C}-327^{\circ} \mathrm{C}$, most of the As in the flue gas condense into a solid phase as $\mathrm{As}_{2} \mathrm{O}_{5}$. EXAF results show that only $\mathrm{Ca}_{3}\left(\mathrm{AsO}_{4}\right)_{2}$ is found in the flue gas, and solid residual samples are collected from the As capture experiments. No other $\mathrm{Ca}-\mathrm{As}-\mathrm{O}$ compounds were identified. This finding is consistent with a number of previous studies on $\mathrm{As}_{2} \mathrm{O}_{3}-\mathrm{CaO}$ reaction in the range $600{ }^{\circ} \mathrm{C}-1000{ }^{\circ} \mathrm{C}$ (Li et al., 2007; Sterling and Helble, 2003). Equations (4-8) were proposed based on the analytical result and previous literature records for the reaction between $\mathrm{As}$ and $\mathrm{CaO}$, as follows:

$$
\begin{aligned}
& \mathrm{CaO}+\mathrm{CO}_{2} \leftrightarrow \mathrm{CaCO}_{3}, \\
& 6 \mathrm{CaO}+\mathrm{As}_{4} \mathrm{O}_{10}(\mathrm{~g}) \rightarrow 2 \mathrm{Ca}_{3}\left(\mathrm{AsO}_{4}\right)_{2}, \\
& 6 \mathrm{CaCO}_{3}+\mathrm{As}_{4} \mathrm{O}_{10}(\mathrm{~g}) \rightarrow 2 \mathrm{Ca}_{3}\left(\mathrm{AsO}_{4}\right)_{2}+6 \mathrm{CO}_{2}, \\
& 6 \mathrm{CaCO}_{3}+\mathrm{As}_{4}(\mathrm{~g})+6 \mathrm{H}_{2} \mathrm{O} \rightarrow 2 \mathrm{Ca}_{3}\left(\mathrm{AsO}_{2}\right)_{2}+6 \mathrm{H}_{2}(\mathrm{~g})+2 \mathrm{CO}_{2}(\mathrm{~g}), \text { (Equation 7) } \\
& 3 \mathrm{CaO}(\mathrm{s})+\mathrm{As}_{2} \mathrm{O}_{3}(\mathrm{~g})+\mathrm{O}_{2}(\mathrm{~g}) \rightarrow \mathrm{Ca}_{3}\left(\mathrm{AsO}_{4}\right)_{2}(\mathrm{~s})
\end{aligned}
$$

\section{Conclusions}

As a waste management strategy, combustion was used to dispose $P$. vittata biomass derived from large-scale As phytoremediation sites in rural areas of China. This research focused on the in site pilot-scale combustion. Considerable amounts of As are emitted in the flue gas due to high As contamination in the biomass and the volatility 
of As during combustion. Blending biomass with chemical sorbent $\mathrm{CaO}$ as emission control strategy remarkably improved the retention of As in the processed ash residual from $12.0 \%$ to $76.3 \%$ when $\mathrm{CaO}$ was blended with the biomass at $10 \%$ of the total fuel weight. Thus, the As emission in the flue gas remarkably decreased. XAFS analysis confirmed that $\mathrm{Ca}_{3}\left(\mathrm{AsO}_{4}\right)_{2}$ is the dominant reaction product in a post-sorption sample. The results of this study provide valuable information on the disposal of harvested As-hyperaccumulators and their biomass, which contains high As concentrations. Results also indicate economic effectiveness of this approach in low income areas with friendly environment.

Acknowledgements This work was supported by the Special research in public service industry, China Ministry of Land and Resources [grant number 201511082-03], Science and Technology Major Project of Guangxi [grant number AA17204047-2], and UK Engineering Physical Sciences Research Council (EPSRC) [Grant No. $\mathrm{EP} / \mathrm{P} 022863 / 1]$. 


\section{References}

Bool L E, Helble J J (1995). A Laboratory Study of the Partitioning of Trace Elements during Pulverized Coal Combustion. Fuel \& Energy Abstracts, 37:880-887

Chen T B, Liao X Y, Huang Z C, Lei M, Li W X, Mo L Y, et al (2006).

Phytoremediation of Arsenic-Contaminated Soil in China. Phytoremediation. Humana Press, $23: 391-402$

Chen T B, Wei C Y, Huang Z C, Huang Q F, Lu Q G, Fan Z L (2002). Arsenic hyperaccumulator Pteris Vittata L . and its arsenic accumulation. Chinese Science Bulletin, 47:902-905

Chesworth S, Yang G, Chang D P Y, Jones A D, Kelly P B, Kennedy I M (1994). The fate of arsenic in a laminar diffusion flame. Combust. Flame, 98:259-266

Contreras M L, Arostegui J M, Armesto L (2009). Arsenic interactions during co-combustion processes based on thermodynamic equilibrium calculations. Fuel, $88: 539-546$

Dhir B, Nasim S A, Samantary S, Srivastava S (2012) Assessment of osmolyte accumulation in heavy metal exposed salvinia natans. International Journal of Botany, 8(3):153-158 
Frandsen F, Dam-Johansen K, Rasmussen P (1994). Trace elements from combustion and gasification of coal-An equilibrium approach. Progress in Energy and Combustion Science, 20:115-138

Gullett B K, Raghunathan K (1994). Reduction of Coal-Based Metal Emissions by Furnace Sorbent Injection. Energy \& Fuels, 8:1068-1076

Guo X, Zheng C G, Xu M H (2004). Characterization of Arsenic emissions from a Coal-Fired power plant. Energy \& Fuels, 18:1822-1826

Helsen L, Van Den Bulck E (2000). Metal behavior during the low-temperature pyrolysis of chromated copper arsenate-treated wood waste. Environmental Science \& Technology, 34:2931-2938

Hirsch M E, Sterling R O, Huggins F E, Helble J J (2000). Speciation of Combustion-Derived Particulate Phase Arsenic. Environmental Engineering Science, $17: 315-327$

Huang Z C, Chen T B, Lei M, Hu T D (2004). Direct Determination of Arsenic Species in Arsenic Hyperaccumulator Pteris vittata by EXAFS. Acta Botanica Sinica, $46: 46-50$

Jadhav R A, Fan L S (2001). Capture of gas-phase arsenic oxide by lime: Kinetic and mechanistic studies. Environmental Science \& Technology, 35:794-799 
Jiang Y, Lei M, Duan L B, Longhurst P (2015). Integrating phytoremediation with biomass valorisation and critical element recovery: A UK contaminated land perspective. Biomass and Bioenergy, 83:328-339

Kertulis-Tartar G M, Ma L Q, Tu C, Chirenje T (2006). Phytoremediation of an arsenic-contaminated site using Pteris vittata L.: a two-year study. International Journal of Phytoremediation, 8: 311-322

Li Y, Tong H, Zhuo Y, Li Y, Xu X (2007). Simultaneous removal of $\mathrm{SO}_{2}$ and trace $\mathrm{As}_{2} \mathrm{O}_{3}$ from flue gas: Mechanism, kinetics study, and effect of main gases on arsenic capture. Environmental Science \& Technology, 41:2894-2900

Liu R, Yang J, Xiao Y, Liu Z (2009). Fate of Forms of arsenic in Yima coal during pyrolysis. Energy and Fuels, 23:2013-2017

Mahuli S, Agnihotri R, Chauk S, Ghoshdastidar A, Fan L S (1997). Mechanism of Arsenic Sorption By Hydrated Lime. Environmental Science \& Technology, $31: 3226-3231$

Neeft J P A, Van Pruissen O P, Makkee M, Moulijn J A (1997). Catalysts for the oxidation of soot from diesel exhaust gases. II. Contact between soot and catalyst under practical conditions. Applied Catalysis B: Environmental, 12:21-31 
Nzihou A, Stanmore B (2013). The fate of heavy metals during combustion and gasification of contaminated biomass-A brief review. Journal of Hazardous Materials, 256-257: 56-66

Pudasainee D, Paur H R, Fleck S, Seifert H (2014). Trace metals emission in syngas from biomass gasification. Fuel Processing Technology, 120:54-60

Ratafia-Brown J A (1994). Overview of trace element partitioning in flames and furnaces of utility coal-fired boilers. Fuel Processing Technology, 39:139-157

Sas-Nowosielska A, Kucharski R, Małkowski E, Pogrzeba M, Kuperberg J M, Kryński K (2004). Phytoextraction crop disposal - An unsolved problem. Environment Pollution, 128: 373-379

Simone M, Barontini F, Nicolella C, Tognotti L (2012). Gasification of pelletized biomass in a pilot scale downdraft gasifier. Bioresource Technology, 116:403-412

Sterling R O, Helble J J (2003). Reaction of arsenic vapor species with fly ash compounds: Kinetics and speciation of the reaction with calcium silicates.

Chemosphere, 51:1111-1119

Struis R P W J, Von S C, Stucki S, Prins R (2002). Gasification reactivity of charcoal with CO2. Part II: Metal catalysis as a function of conversion. Chemical Engineering Science, 57:3593-3602 
Wan X M, Lei M, Yang J (2016). Two potential multi-metal hyperaccumulators found in four mining sites in Hunan Province, China. Catena, 148:67-73

Yan X L, Chen T B, Liao X Y, Huang Z C, Pan J R, Hu T D et al (2008). Arsenic transformation and volatilization during incineration of the hyperaccumulator Pteris vittata L. Environmental Science \& Technology, 42(5):1479

Zhang J P, Wang Y Q, Zhang R G, Muo J Y, Ren D Y (1999). Distribution of Arsenic in Colal and Its Residues. Research of Environmental Sciences, 01:30-32+37

Zhong D X, Zhong Z P, Wu L H, Xue H, Song Z W, Luo Y M (2015). Thermal characteristics and fate of heavy metals during thermal treatment of Sedum plumbizincicola, a zinc and cadmium hyperaccumulator. Fuel Processing Technology, $131: 125-132$ 


\section{Highlights:}

- Pilot-scale combustion is required to treat arsenic-enriched biomass in China

- $\mathrm{CaO}$ addition to arsenic-enriched biomass reduces arsenic emission

- $\mathrm{CaO}$ captures arsenic via chemical adsorption to form $\mathrm{Ca}_{3}\left(\mathrm{AsO}_{4}\right)_{2}$ 


\section{Table 1}

Operational parameters for $P$. vittata combustion

\begin{tabular}{cccccc}
\hline Sample & CaO added in & Atmospheric & $\mathrm{O}_{2}$ content in & Flue gas & Flue gas flow \\
$\mathrm{ID}$ & feedstock $(\%)$ & pressure & flue gas $(\%$ & temp $\left({ }^{\circ} \mathrm{C}\right)$ & rate $\left(\mathrm{m}^{3} \mathrm{~min}^{-1}\right)$ \\
& & $(\mathrm{kPa})$ & by volume $)$ & & \\
\hline $\mathrm{HN}$ & 0 & 99.4 & 14.4 & 46.6 & 16.9 \\
$\mathrm{GX}$ & 0 & 99.2 & 15.7 & 48.0 & 19.7 \\
$\mathrm{JY}$ & 0 & 99.4 & 18.2 & 47.7 & 23.5 \\
$\mathrm{JY}$ & $5 \%$ & 98.5 & 17.0 & 47.7 & 32.1 \\
$\mathrm{JY}$ & $10 \%$ & 98.5 & 17.0 & 47.0 & 32.9 \\
$\mathrm{JY}$ & $15 \%$ & 98.7 & 18.6 & 46.3 & 38.2 \\
\hline
\end{tabular}


Table 2

Proximate and elemental analyses of $P$. vittata

\begin{tabular}{|c|c|c|c|}
\hline Sample ID & $\mathbf{H N}$ & $\mathbf{G X}$ & JY \\
\hline \multicolumn{4}{|c|}{ Proximate analysis on fresh weight basis } \\
\hline Moisture content $(\%)$ & 9.54 & 10.01 & 9.34 \\
\hline Ash content $(\%)$ & 9.4 & 9.9 & 12.44 \\
\hline Volatile matter $(\%)$ & 66.87 & 65.86 & 65.48 \\
\hline Fixed carbon $(\%)$ & 14.19 & 14.23 & 12.74 \\
\hline $\mathrm{CV}\left(\mathrm{MJ} \mathrm{kg}^{-1}\right)$ & 18.26 & 17.67 & 17.26 \\
\hline \multicolumn{4}{|c|}{ Elemental analysis (\%) on DW basis } \\
\hline $\mathrm{C}$ & 47.13 & 46.54 & 44.5 \\
\hline $\mathrm{H}$ & 5.21 & 4.93 & 4.85 \\
\hline $\mathrm{O}$ & 36.63 & 37.61 & 36.77 \\
\hline $\mathrm{N}$ & 1.44 & 0.84 & 1.21 \\
\hline $\mathrm{S}$ & 0.19 & 0.18 & 0.23 \\
\hline
\end{tabular}




\section{Table 3}

Element concentrations ( $\mathrm{mg} \mathrm{kg}^{-1}$ on DW basis) of three $P$. vittata biomass samples

\begin{tabular}{llll}
\hline Element & HN & GX & JY \\
\hline As & $22.1 \pm 9.2$ & $98.4 \pm 21.4$ & $486.0 \pm 41.0$ \\
$\mathrm{P}$ & $1600 \pm 207$ & $1100 \pm 834$ & $1900 \pm 501$ \\
$\mathrm{~K}$ & $19900 \pm 2800$ & $15500 \pm 2900$ & $20200 \pm 6100$ \\
$\mathrm{Na}$ & $62.4 \pm 12.4$ & $55.5 \pm 20.6$ & $99.9 \pm 28.0$ \\
$\mathrm{Ca}$ & $2900 \pm 372$ & $3500 \pm 970$ & $4460 \pm 530$ \\
$\mathrm{Mg}$ & $1560 \pm 660$ & $10500 \pm 340$ & $1870 \pm 130$ \\
$\mathrm{Cu}$ & $11.2 \pm 0.2$ & $8.8 \pm 0.5$ & $17.0 \pm 2.0$ \\
$\mathrm{Zn}$ & $23.9 \pm 2.4$ & $25.2 \pm 12.3$ & $45.0 \pm 8.7$ \\
$\mathrm{Fe}$ & $101 \pm 6$ & $50.4 \pm 7.6$ & $274 \pm 70.4$ \\
\hline
\end{tabular}

Note: All data are presented as the mean of three replicates $(n=3) \pm$ standard deviation. 


\section{Table 4}

Key thermal characteristics of HN, GX, and JY biomass samples

\begin{tabular}{|c|c|c|c|c|c|}
\hline \multirow[t]{4}{*}{ Biomass } & Degradation & Temp ( $\square)$ & Total & Maximum & Temp@ \\
\hline & \multirow[t]{3}{*}{ stage } & & weight & weight loss & maximum \\
\hline & & & loss $(\%)$ & rate $(\% / \square)$ & weight loss \\
\hline & & & & & rate $(\square)$ \\
\hline \multirow[t]{4}{*}{ JY } & 1 & $30-150$ & 7.26 & 0.0008 & 102 \\
\hline & 2 & $150-350$ & 55.85 & 0.0103 & 279 \\
\hline & 3 & $350-510$ & 30.89 & 0.0030 & 371 \\
\hline & 4 & $510-800$ & 0.3 & - & - \\
\hline \multirow[t]{4}{*}{$\mathrm{HN}$} & 1 & $30-120$ & 6.54 & 0.0008 & 102 \\
\hline & 2 & $120-300$ & 50.50 & 0.0138 & 274 \\
\hline & 3 & $300-510$ & 36.96 & 0.0020 & 428 \\
\hline & 4 & $510-800$ & 0.3 & - & - \\
\hline \multirow[t]{4}{*}{ GX } & 1 & $30-150$ & 5.06 & 0.0009 & 99 \\
\hline & 2 & $150-350$ & 52.65 & 0.0103 & 283 \\
\hline & 3 & $>350-510$ & 33.49 & 0.0025 & 396 \\
\hline & 4 & $>510-800$ & 5.9 & - & - \\
\hline
\end{tabular}




\section{Table 5}

As distribution in solid/gaseous residuals and total As recovery

\begin{tabular}{|c|c|c|c|c|c|c|c|c|c|c|}
\hline Sample ID & $\begin{array}{l}\text { Total As in } \\
\text { biomass } \\
\text { feedstock } \\
\text { (g) }\end{array}$ & $\begin{array}{l}\text { As in } \\
\text { Bottom ash } \\
\text { (g) }\end{array}$ & $\begin{array}{l}\text { As in } \\
\text { condensate } \\
\text { fly ash }(g)\end{array}$ & $\begin{array}{l}\text { As in dedusting } \\
\text { fly ash }(\mathrm{g})\end{array}$ & Spray liquid (g) & $\begin{array}{l}\text { Total ash } \\
\text { recovery } \\
(\%)\end{array}$ & $\begin{array}{l}\text { Total As } \\
\text { recovered } \\
\text { in solid } \\
\text { residue }(\mathrm{g})\end{array}$ & $\begin{array}{l}E_{a s h}(\mathrm{As} \\
\text { recovery } \\
\text { in ash) }\end{array}$ & $E_{a s h-a}$ & $\begin{array}{l}E_{\text {total }} \text { (Total } \\
\text { As } \\
\text { recovery) }\end{array}$ \\
\hline $\mathrm{HN}$ & $1.66 \pm 0.69$ & $0.39 \pm 0.032$ & $0.18 \pm 0.020$ & $0.023 \pm 0.01$ & $0.0022 \pm 0.00004$ & $52.5 \%$ & 0.595 & $35.9 \%$ & $68.38 \%$ & $65.3 \%$ \\
\hline GX & $7.38 \pm 1.60$ & $1.33 \pm 0.075$ & $0.22 \pm 0.092$ & $0.0014 \pm 0.0007$ & $0.0019 \pm 0.00006$ & $45.8 \%$ & 1.553 & $21.0 \%$ & $45.85 \%$ & $27.8 \%$ \\
\hline JY control & $36.45 \pm 3.08$ & $3.30 \pm 1.09$ & $0.21 \pm 0.026$ & $0.0015 \pm 0.00003$ & $0.0021 \pm 0.0001$ & $44.6 \%$ & 3.514 & $9.6 \%$ & $21.52 \%$ & $12.0 \%$ \\
\hline \multicolumn{11}{|l|}{$J Y+5 \%$} \\
\hline \multicolumn{11}{|l|}{$\mathrm{CaO}$} \\
\hline \multicolumn{11}{|l|}{$\mathrm{JY}+10 \%$} \\
\hline \multicolumn{11}{|l|}{$\mathrm{CaO}$} \\
\hline \multicolumn{11}{|l|}{$\mathrm{JY}+15 \%$} \\
\hline $\mathrm{CaO}$ & $30.98 \pm 2.61$ & $14.64 \pm 1.68$ & $6.67 \pm 0.33$ & $0.0071 \pm 0.0048$ & $0.0012 \pm 0.0002$ & $81.07 \%$ & 21.318 & $68.8 \%$ & $84.86 \%$ & $69.4 \%$ \\
\hline
\end{tabular}


Table 6

Concentration of other common pollutants in flue gas

\begin{tabular}{ccc}
\hline Index & Concentration & Pollution control standard for hazardous waste \\
& $\mathrm{mg} / \mathrm{m}^{3}$ & incineration $(\mathrm{GB} 18484-2001) \mathrm{mg} / \mathrm{m}^{3}$ \\
\hline Soot & 9.86 & 100 \\
Blackness & Level-I & 500 \\
$\mathrm{NO}_{\mathrm{x}}$ & $60.5-117$ & 400 \\
$\mathrm{SO}_{2}$ & n.d & 100 \\
$\mathrm{HCl}$ & $12.6-20$ & 9 \\
$\mathrm{HF}$ & $0.58-0.75$ & \\
\hline
\end{tabular}

${ }^{\mathrm{a}}$ not detected, detection limit: $2.5 \mathrm{mg} / \mathrm{m}^{3}$ 


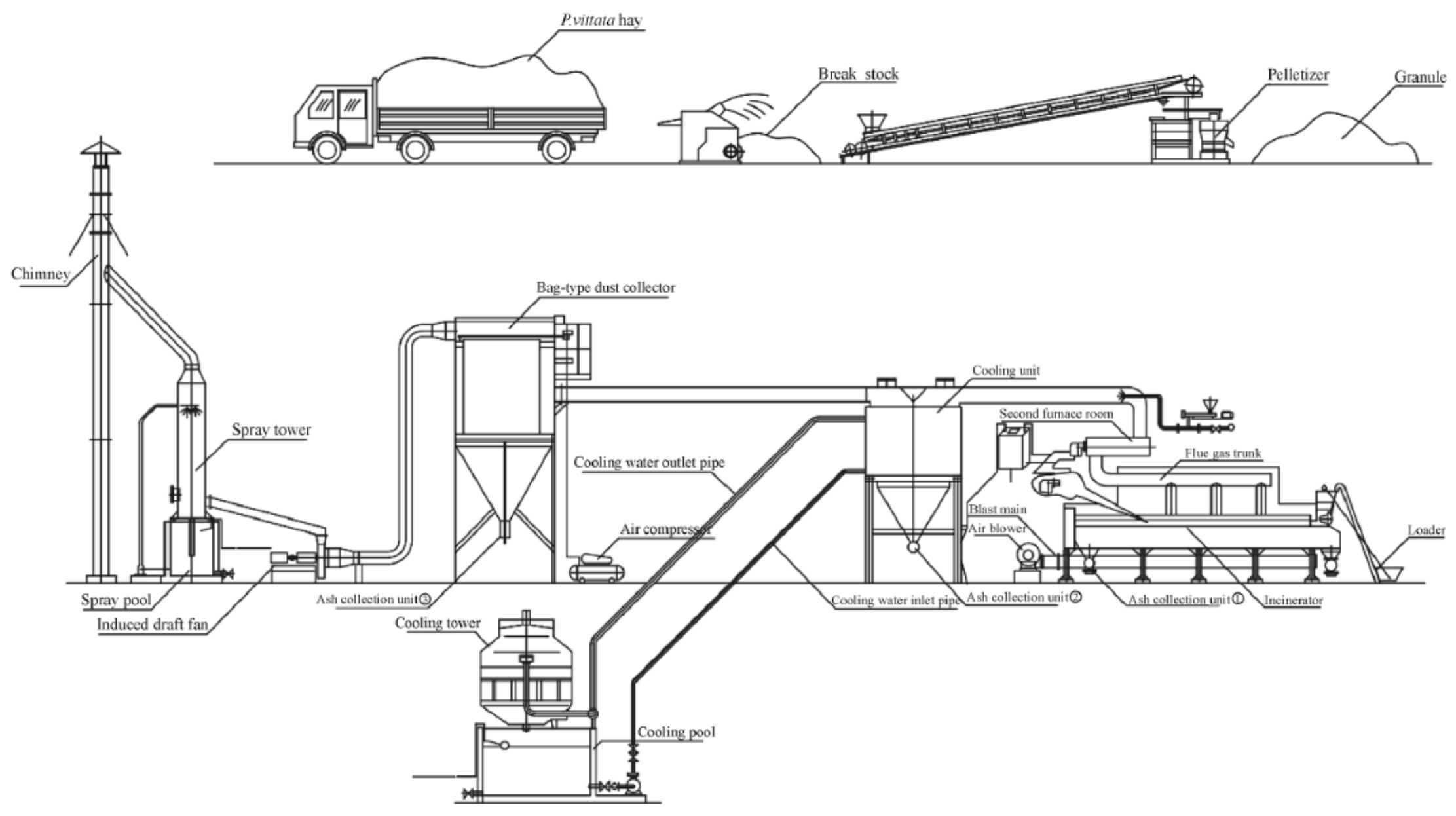

Fig. 1. Schematic of the incineration equipment 

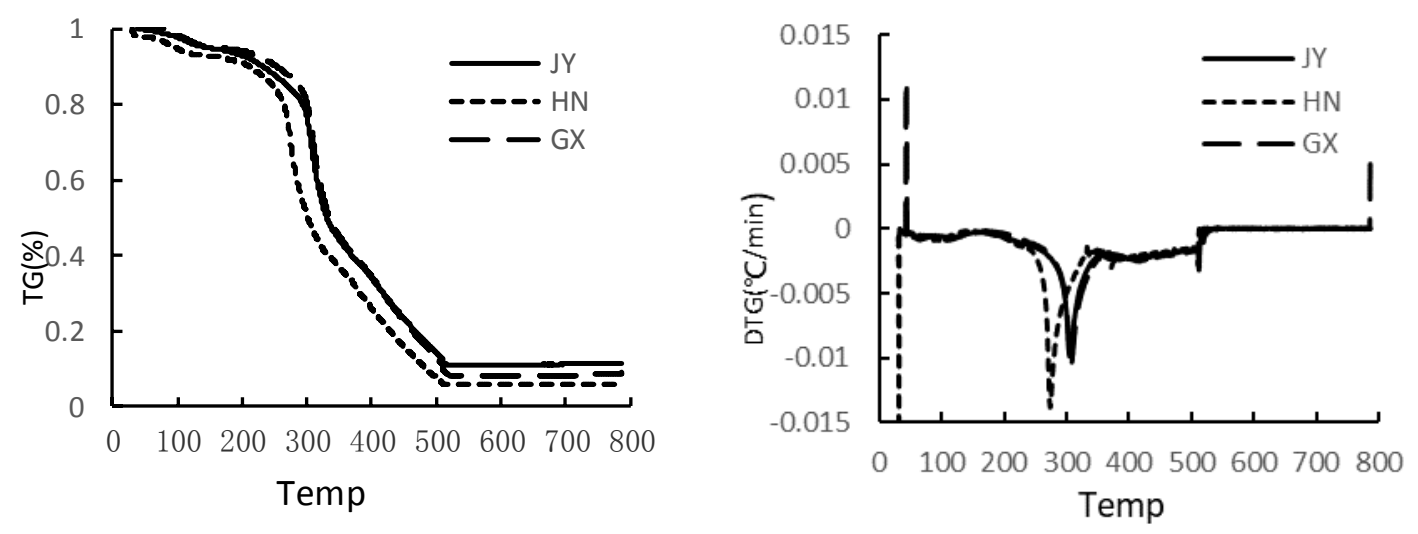

Fig. 2. Thermogravimetric results of $P$. vittata samples: a) TG curves of the three biomass samples, b) DTG curves of the three biomass samples. 


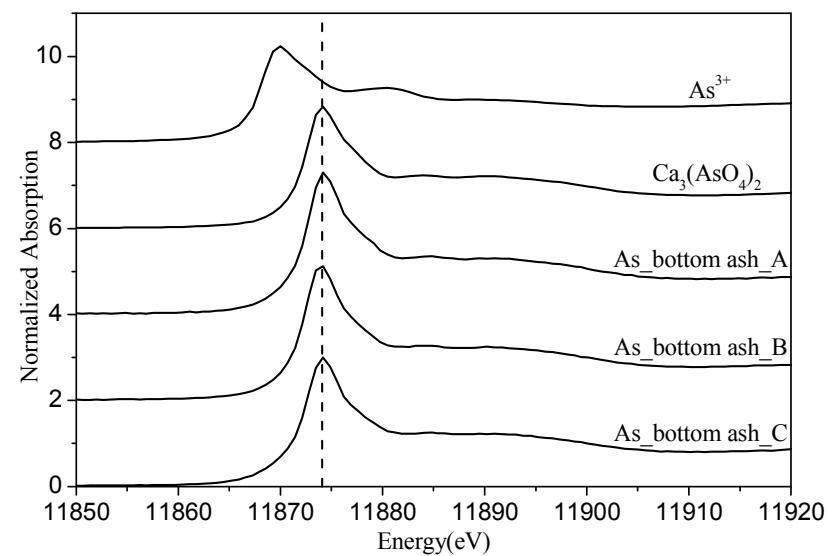

a.) Normalized As K-edge profiles for bottom ash samples and reference As compounds.

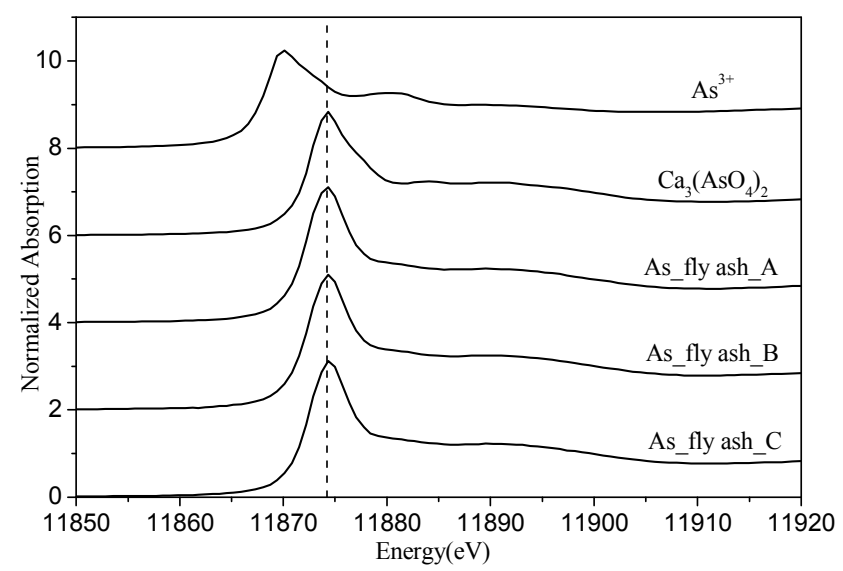

b.) Normalized As K-edge profiles for fly ash samples and reference As compounds

Fig. 3. XANES normalized As K-edge profiles in ash samples: a) Normalized As K-edge profiles for bottom ash samples and reference As compounds. b) Normalized As K-edge profiles for fly ash samples and reference As compounds. Note: Bottom and fly ashes $A, B$, and $C$ are ash samples collected from combustion trials using JY biomass blended with $15 \%, 10 \%$, and $5 \% \mathrm{CaO}$, respectively. 